\title{
Cultural Sociology as Social Research: A conversation with Jeffrey C. Alexander
}

\section{Håkon Larsen}

Institutt for sosiologi og samfunnsgeografi

Universitetet i Oslo

Published in Sosiologisk tidsskrift 1 2014: 75-90.

\section{Introduction}

During recent decades, Jeffrey C. Alexander has been occupied with studying social life from a cultural perspective, developing a cultural sociology concerned with the shaping or constitutive impact of cultural formations and discursive practices on other aspects of social life. In 2003 he published the highly influential book The Meanings of Social Life, which is a collection of substantial papers on various topics analyzed from a cultural sociological perspective, with the programmatic text "The Strong Program in Cultural Sociology" (Alexander and Smith, 2003) leading the way. Ten years have passed. When Alexander was in Oslo in May 2013 giving the Vilhelm Aubert Memorial Lecture, ${ }^{1}$ I met up with him at the Institute for Social Research to discuss the institutionalization of cultural sociology as a school of social research.

\section{The culture in cultural sociology}


HL: In a cultural sociology you argue for employing perspectives from the humanities in studying society. You said in an interview recently that when at college at Harvard in the 1960s you appreciated the courses in drama and literature more than those in social studies, and that this perhaps was the foundation for your interest in cultural sociology (Lynch and Sheldon, 2013). What are the main influences from the humanities in a cultural sociology?

JA: Almost all the ideas of cultural sociology are concepts or theories taken from the humanities, and then re-situated within a study of society, I would say. I think that sociologists are too oriented towards the natural sciences, in terms of both methods and aspirations. We need to go back to the idea of Geisteswissenschaften and Dilthey’s ideas and think of ourselves as part of the human studies.

In terms of specific ideas, I mean, there are several, and one is the idea of discourse. The idea of discourse comes through linguistics, the French discussion of le discours, semiotics, and post-structuralism, but it goes back to ideas of sociolinguistics, structural linguistics, the Prague school. In other words, "discourse” in the human sciences suggests the idea that there is a meta-language, and that it's important to study this langue, and not simply the parole (speech). One of the worst mistakes of conventional sociology is to study speech and not language, to employ this very useful distinction of Saussurian semiotics (Saussure, 1986).

One fundamental element we take from the humanities, then, is the notion of discourse. And that allows us to have a different notion of culture than implied by the old fashioned sociological concept of "values". I've written often in the past, especially during the years that I was beginning to conceive the "strong program", about the problem of a value analysis compared to discourse analysis. 
My approach to cultural sociology takes a relational theory of meaning, which means that meaning, like any discourse, has a binary structure. That's really fundamental to semiotics as it was developed most prominently in Roman Jakobson's work in the Prague school, which drew from Saussure. The binary structure centrally informed the work of Roland Barthes. Barthes, along with Levi-Strauss, was central to the transition from linguistics to social semiotics. Barthes is a key figure in the humanities of the mid-20th century, as much a disciple of Levi-Strauss as Levi-Strauss was a disciple of Jakobson (with whom he worked in New York City during World War II). What I have stressed in my own work is how the binarism of semiotic codes can allow us to make a new connection to Durkheim, in terms of The Elementary Forms (Durkheim, 1912). Semiotic binarism is isomorphic with what Durkheim called the sacred and profane, and this overlap between semiotics and classical sociology gives us even more confidence that we are not radically different as moderns from primitive people. It helps us to overcome the great divide between that which the enlightenment and the founding fathers of sociology established, and that mid-20th century social scientists elaborated, namely that everything that is modern breaks from what is traditional.

Another concept that the strong program in cultural sociology takes from the humanities is the notion of hermeneutics and interpretation. In the humanities, especially in the study of literature, what is central are theories of how to interpret texts. We see an important exemplar of this in Paul Ricoeur's work on hermeneutics, and especially in his critical essay about meaningful action interpreted as a text (1971). Ricoeur goes back to Dilthey in his philosophy of hermeneutics, which had drawn from Schleiermacher. Dilthey insisted that the human sciences always engage in interpretation. If we think of ourselves as interpreting, this doesn't mean, however, that we have to give up the idea of explaining. Interpretation models of meaning can function as explanations. But not in the same way as in the natural sciences' 
model of explanation. Isaac Reed's (2011) recent book Interpretation and Social Knowledge makes this point very nicely.

Another key thing that we take from the humanities is the notion of narrative, which in literary studies is often called genre. It goes back, of course, to Aristotle, and has been developed for literary analysis by people like Northrop Frye, Haydn White, Geoffrey Hartman, and many others. Basically, narrative is plot, the notion of beginning, middle, and end. Thinking about how social discourses are structured, narrative can pretty obviously be conjoined with the notion of binary coding; one can see how discursive binaries get translated as characters, protagonists, and antagonists in social narratives.

Discourse, binary code, and narrative are concepts that informed my earlier work in creating the strong program (with the signal assistance of a series of brilliant students and colleagues). In my more recent work I've been sociologically developing two other concepts from the humanities, one of which is performance (Alexander, Giesen, and Mast, 2006). In sociological theory, people have primarily talked about action. The idea of action comes from both economics' notion of an individual rational actor, but also from legal theory. According to Steven Turner, Weber's notion of action goes back to the notion of a legal definition of an act as displaying responsibility, conscious motivation, and discreteness. I've suggested that performances are maybe a better way of understanding what goes on in social action - better than the idea of “action”. Performances are symbolic actions in time and space. They rely on background representations and project meanings to an audience that's separated from the actor/performer. So, by substituting performance for action we focus on communication. Yet, while symbolic, performance clearly has a pragmatic aspect to it, hence my choice of the general term “cultural pragmatics” for cultural sociology in a performative key. 
In terms of your initial question, I suppose I should point out what's obvious - theories of performance emerge from the humanities. They were brought into sociology by Goffman in a really important way, but it's my strong sense that sociologists in the Goffman tradition have not advanced the symbolic elements of performance. And they certainly have rarely moved beyond micro-sociology and tried to conceptualize performance in a more macro-sociological way. That's what I've tried to do.

The other humanities concept I've recently been working to bring into cultural sociology is the notion of iconic symbols. In social science the concept of material culture is, of course, already of great importance, but mainly within anthropology, for example in the work of Daniel Miller. There has also been, in the work of Latour and his school, a growing interest in the sociology of objects. My own way of looking at this, which I've developed in a few articles and hope to write a book about, is that we need to root a theory of iconic objects in aesthetic theorizing about the senses and forms. I believe we should combine art theory and the philosophy of aesthetics with cultural sociology, as it has developed thus far, to create a proper understanding of the social role of material symbols.

\section{Conducting cultural sociology}

HL: When you do empirical research with these analytical concepts what type of data do you typically analyze?

JA: You need discourse. You need speech. You need to have written records of speech. Most of the students who've worked with me have used media, either television or newspapers. Because only through the exploration of discourse can you reconstruct narratives, codes, performances, and even icons. 


\section{HL: What about policy documents?}

JA: Of course, anything that's written you can use. The good thing about mass media, as compared to say a quote from ethnography or a policy document, is that you know that it is being read widely. You don't necessarily know what the audience interprets from it, but if you explore media over a period of time you do get a sense of audience interpretation because a media organization will provide evidence of how audience/readers are being reconstructed too. It'll have people writing in, responding to changing appearances, and you'll be able to see the focus, because media has to sell newspapers, and they're responsive to opinion.

HL: There's a historical dimension to a lot of your work.

JA: Yes, it seems vital to me to demonstrate not only synchrony - the mark of the structuralist tradition - but diachrony, cultural structures changing, and even being created and destroyed, over the course of historical time. To demonstrate the usefulness of "humanities" concepts in sociology, social change must be primary.

I also use public opinion polls as culture-displaying objects, especially in my work on politics, because they are a critical communicative institution of the civil sphere and also because they give one random sample of "representative” public opinion. But polls are inadequate because they don't allow us to understand “lay meaning-making” and we can’t see the discursive responses they produce. They're a one-sided kind of structuring. On the other hand, polls are very connected to media. A student of mine, Agnes $\mathrm{Ku}$, did a fascinating dissertation many years ago about how media and polling are always tightly connected (see her first ever published article in Sociological Theory (Ku, 1998)). In her examination of the discourses surrounding the British handover of Hong Kong to the Chinese, Agnes showed how the questions pollsters ask reflect what the media's concentrating on now. And then, in turn, how 
the media framing often reflects what are found in polls. Today, most media have their own polls, which they continually employ.

My students and I have also employed as data sources social media and the blogosphere. One can also make use of technical articles that are supposedly scientific and descriptive, and influential public speeches.

Cultural sociologists can also get a great deal out of extended interviewing. I have students who have written their PhDs on fifteen long interviews, up to six hours in length. On the one hand, they're not scientific because there's no ability for randomization, but they produce a tremendous thickness of meaning and cultural structure.

HL: Six hour long interviews?

JA: I mean, for example, two hour long interviews three times.

By the way, Michelle Lamont has produced important work in her first two books (1992, 2000), where she conducted 60-100 interviews of about two hours each. They gave her enough to do a powerful cultural interpretation of class. My only misgiving about Lamont's interview methodology, in The Dignity of the Working Men (2000), for example, is her claim that the interview sample is social representative in a statistical sense. Nevertheless, the work she did is compelling.

I think you can also do cultural-sociological ethnography, if you have reproduced discourse in your published accounts - if you record people's speech actions at length. The problem with most ethnography, from a cultural-sociological point of view, is that it doesn't have many quotations in it. Instead, it is the ethnographer telling you what is actually happening - even Clifford Geertz is guilty on this score. He tells us he is doing thick description, but we have to accept these accounts entirely on his own ethnographic authority. So it's impossible to get a 
sense of actors' meanings in their own terms, which means also one cannot, as a reader, develop any counter-interpretations.

There are major problems of interpretation when you get into iconic and material symbols. Those provide quite a challenge for cultural analysis because it's hard to produce evidence for what are iconic objects. For that, you need discourse, written or verbal talk about the objects.

One can also make good use of commercial advertisements. Phil Smith and I worked with Cristina Poindexter, a recent undergraduate at Yale, whose senior essay ("Technology, Myth, and Social Anxiety,” spring 2013) studied just five advertisements for computer technology, using image analysis, discourse analysis, and film theory.

\section{Cultural sociology and communication studies}

HL: The mass media and social media are important areas for cultural sociology studies. In an article from 2008 in the Journal of Communication, Jefferson Pooley and Elihu Katz wrote that "the sociology of culture subfield has taken up every facet of expressive culture except the mass media [...] sociologists and communication researchers seem to have divided up the labor of studying 'culture', and when their work overlaps they remain in silo-like ignorance of one another. The single step with the greatest potential to help along the ascent resurgence, we suggest, would be to bring the sociology of culture subfield into conversation with communication scholars” (p. 777). Do you agree with this description? And do you think cultural sociology would benefit from being more in touch with communication research?

JA: Well, I suppose what I've just said demonstrates that Pooley and Katz are wrong in suggesting that cultural sociology hasn't made use of mass media! Perhaps, though, they are implying something else as well, which is that the two "fields," cultural sociology and mass 
communication, have little to do with one another - qua fields or disciplines. This indeed is unfortunate, though there have been a few cross-over books; for example, Daniel Dayan and Katz’s Media Events (1992). It’s not incidental, however, that the latter employs a

Durkheimian frame. In terms of my own development as a cultural sociologist, Katz and his work were important for me. I had many interactions with him and the media students and colleagues clustered around him in the late 1970s in Los Angeles, when Elihu worked at Annenberg at the University of Southern California.

The lack of attention inside sociology as a discipline to mass media is unfortunate, but not surprising, really. When sociologists do pay attention to media, it is primarily as a means of power. They shy away from regarding it as fundamental to the projection of social meanings, especially meanings that have relative autonomy from political and economic powers. At the same time, inside media studies, there's not so much relation to sociology, with, instead, a plethora of what some might call "sociology lite" pseudo-theories. I am hoping that this mutually detrimental situation will change if the current effort to create a media section of the American Sociological Association succeeds, which I believe it will.

HL: I think that much of the research coming out of media and communication studies is intra-institutional, or intra-sphere, but that it can be fruitful ground for developing theory on a more societal level. Would you agree with that?

JA: In principle yes. When Katz and Dayan were developing their theory on media events (1992) they were reading my work on Watergate and rituals, and we were having productive conversations about Durkheim. Both media sociologists have been excellent boundarycrossers in terms of humanities theories, in terms of drama, in terms of social theory. Remember, Daniel Dayan did his PhD thesis with Roland Barthes. 
HL: Do you think your form of cultural sociology, with culture as an independent variable, can be combined with a more sociology of culture approach? Do we have to abandon the sociology of culture approach altogether, where culture is treated as a dependent variable, or can it work in harmony with cultural sociology?

JA: The first step is to analyze the internal structures of meaning, of the meanings that exist in the situation you're studying. Maybe there are multiple meanings by different groups, or maybe there are internal contradictions of meaning, or whatever. When you have reconstructed these cultural structures, then you put the structures back into the social system, if you will. And then you look at the relations and tension between the cultural structures and the institutional logics. All of those logics are themselves carriers of meanings, but they express themselves, let's say, in what appear to be “non-cultural” terms, e.g., economically or politically. For example, I am finishing a short book entitled Obama Power (with my former student, Bernadette Jaworsky, who is at Masaryk University in Brno, the Czech Republic) in which we try to understand and explain the vagaries of Obama's first term and his last campaign, and obviously one of the problems one confronts is the role of an economy that failed. You could say that was a material fact, an institutional economic event he couldn't control. You'd be crazy to think you could conduct a cultural sociology of his presidency and re-election that ignored this. But neither can you assert that the logic of economic failure directed or mandated the failure of his presidency, or determined X or Y. The economic problems had to be interpreted by the American people and elites. The challenge that Obama and his opponents faced was how to shape this process of interpretation so that it would contribute to their performative success.

\section{Cultural sociology and the turn towards meaning in sociology}


HL: We have discussed how your work has had an impact on the sociology of culture and the study of media, but considering the scope and ambition of your cultural sociology, in that it can be applied to a wide range of substantial areas of sociology, I would like you to reflect on the fields of sociology in which your perspective has had the most impact? And has it had an impact in disciplines other than sociology?

JA: I don't have a clear sense of the impact of my work, even inside sociology let alone outside it. But, I do know there has been a broad shifting of sensibility within some important pockets of the social sciences, including mass communication, and I would like to believe that my work in cultural sociology and that of like-minded students and colleagues has had something to do with this. There has been a dramatically different "Durkheim" about in sociology and theory since I started bruiting ideas about the late, over and against the middle Durkheim thirty years ago. There's been a vast cultural turn in historical and comparative sociology, which has moved away from Theda Skocpol, Charles Tilly, and Michael Mann, and towards more cultural work. While I may have had some influence here - see the recent work of my former student Anne Kane - it's been as much the impact of Geertz and Foucault via the impact of historical sociologists such as William Sewell Jr.

There has also been new interest in broad cultural traumas, much more frequent evocations of the centrality of social symbols, and a surprising willingness to employ such terms as narrative. And, lately, we are hearing more about social performances in macro-sociology. Political sociology has always been a thread in my work, but it has become more central (Alexander, 2010). Some students of mine have really moved into that field, like Jason L. Mast, who has just published a book on the Clinton presidency called The Performative Presidency (2012). If you look at social movement literature, you also see a powerful cultural turn over the past ten years, in terms of new work in emotion and narratives, and in symbolic kinds of mobilization. Again, there is no sense that these new strands can be linked directly to 
my work, but perhaps what I've written over the past two decades, especially, has had some general effect. Certainly, my closer colleague at Yale (and before) Ron Eyerman has made critical moves in social movement research that have created openings to cultural sociology.

HL: There's been an important turn towards studying meaning in many fields of sociology.

JA: Yes, this is exactly what I was trying to suggest. We are in the midst of an immense “cultural” transformation of various fields. We can see new, strong cultural sociological studies emerging in studies of immigration, morality, globality, etc.

In economic sociology there's been a big turn towards what's been called “cultural economic sociology”. In any direct sense, this is primarily because of the influence of Viviana A. Zelizer, with whom I've been close to for thirty years. Viviana’s work has been revolutionary, as she has made the same move from neofunctionalism to cultural codes and narratives. This reflects a broad shift in the intellectual Zeitgeist, not the impact of my work per se. Recently, we have just hired a young man named Frederick F. Wherry as a professor at Yale. He wrote a book on the cultural sociology of markets (2012) and his research brings together strands of Zelizer's and my own work.

I suppose my point here is that I see my own work as part of a very broad intellectual movement, which you yourself are writing about (Larsen, 2013). It began in the middle of the eighties and came after the cultural turn that was around Geertz. It had its European manifestations in the Birmingham school, Foucault, and the cultural Marxists like Bourdieu. This extraordinarily significant movement is what I would call "the cultural turn” in the human sciences. The strong program in cultural sociology is one distinctive theory and research program to have emerged from this movement. 


\section{The break with critical sociology}

HL: Bourdieu has had a massive impact on Norwegian sociology, and still has a high standing, especially in studies of stratification and cultural consumption. On several occasions you have criticized Bourdieu’s sociology of culture. What do you consider the main weaknesses and strengths in Bourdieu's theories of culture?

JA: Let’s start with the strengths. I regard Bourdieu as part of the great movement of neoMarxist revisionism that starts with Lukács and goes on through Gramsci, Althusser, Sartre, the Frankfurt and Birmingham school. I argued in my 1982 book (Alexander, 1982) that Marxism continually revived itself by incorporating the relative autonomy of superstructures, making use of what was available in the cutting edges of cultural analysis at that time. I think one mark of Bourdieu's achievement is how he was able to "revise” orthodox Marxism by putting semiotics and structuralism to work. He understood hermeneutical reconstruction, and he also had the creative intellectual capacity, the theoretical and philosophical sophistication, to find a way to incorporate a theory of meaning with structures of stratification. That was a great accomplishment. And this was not only conceptual. Bourdieu had a wonderful facility as a cultural analyst. In his writings, people get a sense of meaning, which of course he reconstructed as opposing sets of binary codes.

So Bourdieu combined a really brilliant theoretical mind with great empirical abilities, a combination that is unusual in any field.

Finally, Bourdieu was also a radical social critic, engaging with abandon in what Ricoeur (1981) called the hermeneutics of suspicion. His work is filled with bitter indignation at the perverted justice of society, but it is also leavened at times by irony and sarcasm, though perhaps not with as much aesthetic grace as is the work of another capitalist critic, Thorstein Veblen, and his The Theory of the Leisure Class (1899). 
Bourdieu's ability to interweave high theory, dense empirical research, and bitingly bitter ideology-critique makes him deeply appealing for many social scientists who are often also radically committed, and also for lay readers who are equally disgusted by the hypocrisies of their societies.

The failure of Bourdieu's program, in my opinion, is that he doesn't recognize that culture has relative autonomy from social structure. In fact, the whole point of Bourdieu is to tie meaning to structure, and to demonstrate that meaning is constructed in an instrumental way to defend a position in a field, or to gain power in a field. To me this is terribly misleading. I have made the analytical case for the relative autonomy of culture throughout my writings. But perhaps here I might put the case in a more substantive and historical manner, having just contributed an essay for Sociologica on my old teacher Robert Bellah’s (2011) recent magnum opus, Religion in Human Evolution. I agree with the seminal “Weberian” understanding - as interpretively mediated not only by Bellah but, perhaps even more significantly, by Shmuel Eisenstadt - that the very basis of contemporary societies was laid by religious developments in what has, since Karl Jaspers, come to be called the Axial Age. During the first millennia $\mathrm{BC}$, the high religions sharply separated the sacred from the mundane, creating a transcendental religious understanding that systematically offered, for the first time, the possibility of social critique. This breakthrough also allowed intellectuals and hermeneutists and religious people to form their own elites that had some autonomy from political and economic centers. So, not only analytically but historically, culture has relative, and relevant, autonomy. Modernity is about the relative independence of meaning that allows criticism and that allows separation. We need to recognize that meaning has its own interior logics, its own cultural logics, and we need to possess tools to analyze that. It doesn't mean we ignore institutions, but we need ways of isolating the internal logics of meaning if only so that we 
can observe how often they are in tension with structural positions rather than, as Bourdieu continuously asserts, merely complementing them.

HL: A former student of Bourdieu, Luc Boltanski, in cooperation with Laurent Thévenot has developed a pragmatic sociology which has been labeled a sociology of critique, as opposed to Bourdieu's critical sociology. Do you see their work as part of the same tradition your work is in?

JA: Yes and no. I think Boltanski and Thévenot's De la justification (1991), which is translated as On Justification (2006), is a major work. It's so very important that they broke with Bourdieu by recognizing the plurality of social spheres, not privileging one over another. I do believe that they were strongly influenced by Michael Walzer's (1983) earlier book, Spheres of Justice. I also appreciate how Boltanski and Thévenot attached their orders of worth to the different cultural logics of institutionally separated spheres. They theorized that political and social conflicts inside those spheres, and between those spheres, are organized with references to these cultural logics of justification. When I spent a year in Paris, 19931994, Thévenot and I met four times, as I recall, engaging in some long and very interesting discussions.

What I see as a problem in their program is that they don't explicitly engage in inductively hermeneutical work. They enter into the actual discourses of people with the aim of coming up with reconstructions of the meanings actors employ in their actual interactions. As I read pragmatic sociology, there is a little bit of a deductive logic, in that the logics of those spheres is pretty much given rather than worked at, constituting an end not a beginning of meaninganalysis (though, to be fair, they recognize that new spheres and new logics come into being at different historical times). In other words, I see this as “pragmatic sociology” but not “cultural pragmatics”. 
Another way to put this is that, in the 1991 book, they used the notion of "logic" too much, an idea of logical argumentation that they took over from a Belgian pragmatic philosopher named Chaïm Perelman. For myself, I don't believe that social actors actually engage in argumentation in this way and it is for this reason that we need to move more towards notions of storytelling, narrative, binaries, pollution, purification, ritual, performance, and icon.

HL: I think this strand of sociology has a lot in common with American repertoire theory in cultural sociology. I am, of course, thinking of Ann Swidler, but also Michéle Lamont, who has worked together with Thévenot on comparative cultural sociology (Lamont and Thévenot, 2000). How do you see your work compared to this repertoire theory?

JA: Swidler and I have been (personally quite friendly) intellectual opponents since we were in graduate school together at Berkeley. I considered her article on culture in action (Swidler, 1986) deeply misleading, the wrong place to try to begin creating a cultural sociology. For me, this early work, and the work that followed it until recently, made a straw man out of strong cultural theories, suggesting that if you emphasize the power of culture you do so at the expense of theories that allow contingency, creativity, and pragmatic action. Swidler's approach seemed to suggest that, for cultural sociology to acknowledge the creativity of the actor, it must eschew the idea of limiting background cultural structures, or repertoires, for the idea that actors make up their own meanings. So, in this line of her thought, Swidler sharply juxtaposed her approach with structuralism and semiotics, insisting that meaning is generated from, let's say, the grassroots and upwards, rather than from structures of meaning and downwards.

In her book on love, Swidler (2001) makes a turn towards practices, suggesting that the culture of love is nothing other than the practice of marriage, indeed that the practices of being married are what generate the meanings of love. My feeling is deeply to the contrary. 
We need to start with the resources of textuality, language, narratives and codes, which have carried restricted but powerful "meanings of love” over centuries. At the same time, though, we need to understand, as semiotics and post-structuralism did, that sets of structured signifiers don't have any determinant power over action, that they're interpreted creatively in the course of relating signifiers to signified, which is in speech.

In her polarizing early and middle understandings of culture, I believe Ann was much influenced by Herbert Blumer, the student of George Herbert Mead who created the term “symbolic interactionism” and who was a big voice at Berkeley during our grad school years. Like Blumer, Ann’s work portrays what I conceive as an overly concrete view of action. During her most recent writing, however, for example in her jointly authored “Condom Semiotics” (Tavory and Swidler, 2009), one finds what I believe to be a major break. Without acknowledging it, in this work Swidler actually inverts her insistence that meaning is generated by the pragmatics of action. In this sense, I must admit that I feel there has been a convergence between her later work and my own. I find “Condom Semiotics” to be thoroughly complementary with the strong program. In this context, I would acknowledge that the central theoretical interests of my cultural sociological work have changed over time. My early interest was in finding the tools to reconstruct deep meanings, as in the discourse of civil society. Of course, even in this early work, e.g., my 1988 essay on Watergate (Alexander, 1988), I was very careful to say that the culture structures I had revealed did not, in themselves, determine the social actions that constitute Watergate. It was all indeterminate, even the "ritual" constituted by the Senate public hearings in the summer of 1973. At the same time, it’s fair to say that what I was really most interested in at this stage of my development was structures of meaning. This is what I wanted to make my fellow sociologists more aware of. After I had established the importance of such cultural structures, I began to 
focus more explicit theoretical attention on the pragmatics of action, my social performance theory being the most conspicuous result.

I should add, of course, that while I see Ann Swidler as a pragmatist, she's hardly the only one. There's the influential American school called neo-institutionalism with John Meyer et al., the series of theoretical essays espousing pragmatism that stretches from Hans Joas to Mustafa Emirbayer and Filipe Carreira da Silva. For my money, there's been too much emphasis on pragmatism and not enough on culture.

\section{The future of the strong program}

HL: In 2008 you said in an interview that your Center for Cultural Sociology at Yale could not "possibly afford to start a journal or to financially sponsor visiting fellowships” (Cordero, Carballo, and Ossandón, 2008: 512). But in 2013 you launched the American Journal of Cultural Sociology (AJCS), together with Philip Smith and Ronald N. Jacobs. It seems that cultural sociology has taken another step towards its institutionalization as a school of social research. What do you want to achieve with this journal?

JA: First, let me say that, yes, we're definitely a "school” in the intellectual sense but not a school in the sense of a highly funded research institution. In contrast with the latter, we are scarcely funded, though Yale and the Department of Sociology have been generous in regard to student funding, administrative assistance, and funding for the travel and room and board of outsider presenters. As for the AJCS, this journal is already creating a vital space for strong cultural sociology to be published and to flourish. On the one hand, cultural sociology should not be focused on its own navel and turned into a sect. It's an approach that has entered into every specialized subfield of sociology, and for this reason I hope people will continue to publish in many different journals. Yet, at the same time, I think there's an advantage in 
concentrating some significant slice of cultural sociology in one place, so that the breadth and depth of it can be well displayed, so that arguments can become more easily intertextual and mutually referential, so that real scientific accumulation can take place. When they publish in the AJCS, social scientists don't have to defend the legitimacy of a cultural approach; they can concentrate on the task at hand. By contrast, when you publish something, let's say in the American Journal of Sociology, American Sociological Review or Theory and Society, you have to go out of your way to explain why "it's alright to do culture here”, and you need, as a result, to spend a lot of time critiquing non-cultural approaches. You have to create a justification.

At the AJCS, you don't have to do that. You can engage different approaches within cultural sociology; you can just develop your own model without feeling the need to provide a metajustification towards non-cultural others. I'm hoping this freedom will allow for the development and elaboration of the paradigm, on the one hand, but we also want the AJCS to be a wide tent, displaying the plurality and diversity that marks the entire field. It would be good to have Bourdieuian, critical, pragmatic, and other "weak program" approaches in the journal, though we would want them to engage with strong program work. We want the AJCS to be a protected space of opinion. There can be more productive critical scrutiny brought to bear on cultural sociological work if some significant part of it appears side by side, year after year, in the same journal.

\section{Acknowledgements}

I am grateful to Jeffrey Alexander for his thorough review of the transcripts from the interview, to Trygve Gulbrandsen for taking care of the practical arrangements of the interview, and Pål Halvorsen for transcribing the interview. 


\section{About the author}

Håkon Larsen is a postdoctoral fellow at the Department of Sociology and Human Geography at the University of Oslo. His research interests include cultural sociology, media and communication, and cultural policy. In 2013 he published the book Den nye kultursosiologien (Universitetsforlaget). His most recent article (2014) is titled “Legitimation Work in State Cultural Organizations: The Case of Norway” (International Journal of Cultural Policy).

\section{Endnotes}

${ }^{1}$ This as an annual lecture arranged by the Department of Sociology and Human Geography, University of Oslo, and the Institute for Social Research in Oslo, in memory of Vilhelm Aubert, one of the founding fathers of Norwegian sociology.

\section{References}

Alexander, J. C. (1982) Theoretical Logic in Sociology. Vol 2. The Antinomies of Classical Thought. Marx and Durkheim. Berkeley, CA: University of California Press.

Alexander, J. C. (1988) 'Culture and Political Crisis: "Watergate" and Durkheimian Sociology', in Alexander, J. C. (ed.) Durkheimian Sociology: Cultural Studies (187224). Cambridge: Cambridge University Press.

Alexander, J. C. (2003) The Meanings of Social Life. A Cultural Sociology. New York, NY: Oxford University Press. 
Alexander, J. C. (2010) The Performance of Politics. Obama's Victory and the Democratic Struggle for Power. New York, NY: Oxford University Press.

Alexander, J. C., and Smith, P. (2003) 'The Strong Program in Cultural Sociology. Elements of a Structural Hermeneutics', in Alexander, J. C. (ed.) The Meanings of Social Life. A Cultural Sociology (11-26). Oxford: Oxford University Press.

Alexander, J. C., Giesen, B. and Mast, J. L. (2006) Social Performance. Symbolic Action, Cultural Pragmatics, and Ritual. Cambridge: Cambridge University Press.

Bellah, R. (2011) Religion in Human Evolution. From the Paleolithic to the Axial Age. Cambridge, MA: Harvard University Press.

Boltanski, L., and Thévenot, L. (1991) De la justification. Les économies de la grandeur. Paris: Gallimard.

Boltanski, L., and Thévenot, L. (2006) On Justification. Economies of Worth. Princeton, N.J: Princeton University Press.

Cordero, R., Carballo, F. and Ossandón, J. (2008) 'Performing Cultural Sociology. A Conversation with Jeffrey Alexander', European Journal of Social Theory, 11: 501520.

Dayan, D., and Katz, E. (1992) Media Events. The Live Broadcasting of History. Cambridge, MA: Harvard University Press.

Durkheim, É. (1912) Les formes elementaires de la vie religieuse. Le systeme totemique en Australie. Paris: Felix Alcan.

Ku, A. (1998) 'Boundary Politics in the Public Sphere: Openness, Secrecy, and Leak', Sociological Theory, 16: 172-192.

Lamont, M. (1992) Money, Morals and Manners: The Culture of the French and American Upper-middle Class. Chicago, IL: University of Chicago Press. 
Lamont, M. (2000) The Dignity of Working Men. Morality and the Boundaries of Race, Class, and Immigration. Cambridge, MA: Harvard University Press.

Lamont, M, and Thévenot, L. (2000) Rethinking Comparative Cultural Sociology: Repertoires of Evaluation in France and the United States. Cambridge: Cambridge University Press.

Larsen, H. (2013) Den nye kultursosiologien. Kultur som perspektiv og forskningsobjekt. Oslo: Universitetsforlaget.

Lynch, G., and Sheldon, R. (2013) 'The Sociology of the Sacred: A Conversation with Jeffrey Alexander', Culture and Religion: An Interdisiplinary Journal, 14: 253-267.

Mast, J. L. (2012) The Performative Presidency. Crisis and Resurrection During the Clinton Years. Cambridge: Cambridge University Press.

Pooley, J., and Katz, E. (2008) 'Further Notes on Why American Sociology Abandoned Mass Communication Research', Journal of Communication, 58: 767-786.

Reed, I. (2011) Interpretation and Social Knowledge. On the Use of theory in the Human Sciences. Chicago, IL: University of Chicago Press.

Ricoeur, P. (1971) 'The Model of the Text. Meaningful Action Considered as a Text', Social Research, 38: 529-562.

Ricoeur, P. (1981) Hermeneutics and the Human Sciences. Essays on Language, Action and Interpretation. Cambridge: Cambridge University Press.

Saussure, F. d. (1986) Course in General Linguistics. Chicago, Ill: Open Court .

Swidler, A. (1986) 'Culture in Action: Symbols and Strategies', American Sociological Review, 51: 273-86.

Swidler, A. (2001) Talk of Love. How Culture Matters. Chicago: University of Chicago Press. Tavory, I., and Swidler, A. (2009) 'Condom Semiotics: Meaning and Condom Use in Rural Malwi', American Sociological Review, 74: 171-189. 
Veblen, T. (1899) The Theory of the Leisure Class. An Economic Study of Institutions. New York, NY: Macmillan.

Walzer, M. (1983) Spheres of Justice. A Defence of Pluralism and Equality. Oxford: Blackwell.

Wherry, F. F. (2012) The Culture of Markets. Cambridge: Polity. 